\title{
PENGARUH MODEL PEMBELAJARAN KOOPERATIF TIPE JIGSAW DAN MOTIVASI BELAJAR TERHADAP PRESTASI BELAJAR ILMU FISIOLOGI OLAHRAGA
}

\author{
Made Budiawan ${ }^{1}$, Ni Luh Kadek Alit Arsani² \\ 1.2 Jurusan Ilmu Keolahragaan Fakultas Olahraga dan Kesehatan \\ Universitas Pendidikan Ganesha \\ Singaraja, Indonesia \\ e-mail: budiawan ajus@yahoo.co.id, alit arsani@yahoo.com
}

\begin{abstract}
Abstrak
Tujuan penelitian ini adalah untuk mengetahui: 1) Pengaruh model pembelajaran Kooperatif tipe Jigsaw terhadap prestasi belajar IImu Fisiologi Olahraga. 2) Pengaruh motivasi terhadap prestasi belajar Ilmu Fisiologi Olahraga. 3) Interaksi antara model pembelajaran Kooperatif tipe Jigsaw dan motivasi terhadap prestasi belajar IImu Fisiologi Olahraga.

Metode penelitian yang digunakan adalah metode eksperimen. Penelitian dilaksanakan bulan April sampai Desember 2012. Populasi adalah mahasiswa Jurusan IImu Keolahragaan dan Pendidikan Kepelatihan Olahraga Fakultas Olahraga dan Kesehatan Universitas Pendidikan Ganesha. Sampel adalah mahasiswa semester III yang terdiri dari dua kelas, yaitu kelas A sebagai perlakuan dan kelas B sebagai kontrol. Karena populasinya kecil, maka tidak dilakukan sampling. Teknik pengumpulan data menggunakan angket motivasi dan tes prestasi belajar. Teknik analisis data menggunakan Analisis Varian Dua Jalur.

Hasil analisis data pada taraf signifikansi $\alpha=0,05$ sebagai berikut: (1) Prestasi belajar mahasiswa yang diajarkan dengan model Pembelajaran Kooperatif tipe Jigsaw (mean=60,81) lebih baik dari pada mahasiswa yang diajarkan dengan model konvensional (mean=60,21) diperoleh nilai statistik 7,234 dengan signifikansi 0,002. (2) Prestasi belajar mahasiswa dengan motivasi tinggi (mean $=71,05$ ) lebih baik daripada mahasiswa yang belajar dengan motivasi rendah (mean $=50,00$ ) diperoleh nilai statistik 146,905 dengan signifikansi 0,000 . (3) Terdapat interaksi pengaruh antara model pembelajaran dan motivasi dalam meningkatkan prestasi belajar pada mata kuliah IImu Fisiologi Olahraga diperoleh nilai statistik 12,342 dengan signifikansi 0,001.

Simpulannya adalah bahwa model pembelajaran kooperatif tipe Jigsaw lebih baik daripada model konvensional, dan motivasi belajar yang tinggi lebih baik daripada motivasi belajar yang rendah. Dengan demikian motivasi tinggi sangat berpengaruh terhadap prestasi belajar, dan pembelajaran dengan model Kooperatif tipe Jigsaw lebih tepat dilaksanakan.
\end{abstract}

Kata-kata Kunci: Pembelajaran Kooperatif tipe Jigsaw, motivasi belajar, prestasi belajar.

The objectives of this research are to investigate: (1) effect between the cooperative learning model towards the learning achievement in sport physiology; (2) effect between the high learning motivation and the low learning motivation towards the learning achievement in sport physiology; (3) interaction of effect between the learning model and the learning motivation towards the learning achievement in sport physiology.

This research used an experimental research method. It was conducted from April to December 2012. Its population was all of the students of Sport Science and Coach Education, the Faculty of Sport and Health, Ganesha University of Education . The samples of the research were the students in Semester III consisting of two classes, Class A and 
Class B. The former was a treatment class and the latter was control one. Due to its small number of population, the research did not employ a certain sampling technique to gather is samples. The data of the research were gathered through questionnaire of learning motivation and test of learning achievement in sport physiology. The data were then analyzed by using a two-way analysis of variance (ANOVA).

The result of the analysis at the significance level of $\alpha=0,05$ are as follow: (1) the learning achievement of the students taught with the cooperative learning model (mean $=60,81$ ) is better than that of students taught with convensional learning model (mean $=60,21$ ) as indicated by statistic value 7,234 with significance 0,002 . (2) the learning achievement of the students with the high learning motivation (mean=71,05) is better than that of the students with the low learning motivation (mean $=50,00$ ) as indicated by statistic value 146,905 with significance $0,000.9$ (3) there is significant interaction of effect between the learning model and the learning motivation towards the learning achievement in sport physiology is indicated by statistic value 12,342 with significance 0,001 .

Based on the result of the research, a conclusion is drawn that the proposed hypothesis are all verified; the cooperative learning model contributes better to the learning achievement in sport physiology than the convensional learning model, and the high learning motivation contributes better to the learning achievement in sport physiology than the low learning motivation. Therefore, the high motivation very much influences the learning achievement, and the cooperative learning model is more appropriate to be implemented than convensional learning model.

Key words: cooperative learning model, learning motivation, and learning achievement.

\section{PENDAHULUAN}

Dunia pendidikan kita ditandai oleh disparitas antara pencapaian academic standard dan performance standard. Faktanya banyak peserta didik menyajikan tingkat hafalan yang baik terhadap materi ajar yang diterimanya, namun pada kenyataannya mereka tidak memahaminya. Sebagian besar dari peserta didik tidak mampu menghubungkan antara apa yang mereka pelajari dengan bagaimana pengetahuan tersebut akan dipergunakan atau dimanfaatkan (Suprijono. A, 2010).

Disparitas terjadi karena pembelajaan selama ini hanyalah suatu proses pengkondisian yang tidak menyentuh realitas alami. Pembelajaran berdasar atas realitas artifisial. Aktivitas kegiatan belajar mengajar selama ini merupakan pseudo pembelajaran. Terdapat jarak yang cukup jauh antara materi yang dipelajari dengan peserta didik sebagai insan yang mempelajarinya. Materi yang dipelajari terpisah dengan peserta didik yang mempelajarinya (Sardiman, 2011).

Pembelajaran seharusnya menjadi aktivitas bermakna yakni pembebasan untuk $\begin{aligned} & \text { mengaktualisasi } \\ & \text { kemanusiaan, }\end{aligned}$ seluruh $\begin{array}{r}\text { potensi } \\ \text { bukan }\end{array}$
sebaliknya. Pertanyaannya bagaimana menemukan cara terbaik menciptakan pembelajaran bermakna? Proses belajar merupakan proses perubahan seseorang yang dapat dinilai hasilnya dari perubahan yang dilakukan. Dalam proses belajar yang baik dibutuhkan suatu strategi pembelajaran yang tepat sehingga proses belajar dapat dikatakan berhasil dengan baik (Sanjaya.W 2008).

Pendidikan merupakan elemen yang sangat penting untuk menciptakan sumber daya yang berkualitas, cerdas, damai, terbuka, demokratis, dan mampu bersaing serta dapat meningkatlan kesejahteraan semua warga Negara Indonesia. Dengan sumber daya manusia yang bermutu diharapkan dapat menghadapi berbagai perubahan dan tantangan globalisasi yang sedang dan akan terjadi, oleh karena itu program pendidikan hendaknya senantiasa ditinjau dan diperbaiki. Sejalan dengan laju perkembangan dan perubahan yang mempengaruhi pembangunan bidang pendidikan, maka dibutuhkan tenaga 
pendidik yang profesional yang dapat melaksanakan proses belajar mengajar sesuai dengan standar yang ada. Suatu profesi dapat dikatakan profesional bila telah menempuh pendidikan yang cukup untuk memenuhi kompetensi profesionalnya (Undang-Undang RI, 2006).

\begin{tabular}{llll}
\multicolumn{2}{c}{ Menurut } & kondisi yang ada di \\
Jurusan IImu & Keolahragaan Fakultas \\
Olahraga dan & Kesehatan Universitas
\end{tabular} Pendidikan Ganesha tampaknya masih perlu dilakukan pengkajian model pembelajaran yang efektif untuk meningkatkan hasil belajar. Salah satu mata kuliah yang diajarkan adalah fisiologi olahraga. Sebagai seorang calon teknokrat dibidang olahraga, mahasiswa dituntut untuk memahami matakuliah ini dengan baik. Berdasar hasil ujian akhir mahasiswa tahun ajaran 2008-2009 masih terdapat banyak mahasiswa yang memperoleh hasil yang tidak memuaskan. Sebaran nilai yang diperoleh adalah D (29\%), C (51\%), B $(12 \%)$, A (8\%). Hal ini mengindikasikan bahwa masih memerlukan usaha yang lebih keras untuk meningkatkan kualitas hasil belajar mahasiswa. Selama ini proses belajar yang terjadi masih menerapkan metode konvensional berupa ceramah dan diskusi. Metode pembelajaran tersebut membuat mahasiswa lebih tergantung pada dosen dan menganggap jika tidak ada dosen maka tidak ada proses belajar mengajar. Selain itu mahasiswa tidak siap menerima pelajaran dan kurang aktif selama proses belajar mengajar.

Model pembelajaran kooperatif tipe jigsaw merupakan model pembelajaran yang mampu mengajak mahasiswa untuk berpikir secara aktif dan kreatif dalam proses pembelajaran. Model ini tidak hanya mengembangkan kemampuan intelektual tetapi seluruh potensi yang ada, termasuk pengembangan emosional dan pengembangan keterampilan. Dengan menerapkan model pembelajaran ini akan melatih mahasiswa berani mengemukaan pendapat, bekerja sama, mengembangkan diri, dan bertanggungjawab secara individu, saling ketergantungan positif, interaksi personal dan proses kelompok. Penggunaan model pembelajaran ini secara efektif dan efisien akan mengurangi monopoli dosen dalam penguasaan jalannya proses pembelajaran, dan kebosanan siswa dalam menerima pelajaran akan berkurang (Anita Lie,2010).

Berdasarkan beberapa penelitian bidang pendidikan dilaporkan bahwa penerapan model pembelajaran kooperatif dapat memotivasi dan melibatkan para siswa dalam proses belajar mengajar untuk meningkatkan hasil pembelajaran (Tsay. M and Brady. M, 2010). Selain dengan berinovasi dalam penerapan model pembelajaran, hasil belajar juga ikut dipengaruhi oleh faktor lain. Salah satu faktor yang dimaksud adalah motivasi belajar siswa. Motivasi belajar yang tinggi diperkirakan akan meningkatkan prestasi belajar. Menurut Prastya Irawan dkk, mengutip hasil penelitian Fyan dan Maehr mengatakan bahwa faktor motivasi sangat berperan dalam belajar. Walberg dkk menyimpulkan bahwa motivasi mempunyai kontribusi antara 11-20 persen terhadap prestasi belajar. Studi yang dilakukan Suciwati menyatakan bahwa motivasi berkontribusi sebesar 36\%, sedangkan McClleland menunjukkan bahwa motivasi berprestasi mempunyai kontribusi sampai $64 \%$ terhadap prestasi belajar (Tsay. $M$ and Brady. M, 2010).

Menyadari pentingnya inovasi model pembelajaran yang dilakukan untuk meningkatkan hasil belajar, maka perlu dilakukan penelitian tentang: Pengaruh model pembelajaran kooperatif tipe Jigsaw dan motivasi belajar terhadap prestasi belajar ilmu fisiologi olahraga (pada mahasiswa Jurusan IImu Keolahragaan Fakultas Olahraga dan Kesehatan Universitas Pendidikan Ganesha Singaraja). Rumusan masalah adalah:1) Apakah ada pengaruh model pembelajaran kooperatif tipe Jigsaw terhadap prestasi belajar IImu Fisiologi Olahraga?, 2) Apakah ada pengaruh motivasi belajar terhadap prestasi 
belajar IImu fisiologi Olahraga, 3) Apakah terdapat pengaruh interaksi antara model pembelajaran kooperatif tipe Jigsaw dan motivasi belajar terhadap prestasi belajar IImu Fisiologi Olahraga. Tujuan untuk mengetahui peengaruh model pembelajaran kooperatif tipe Jigsaw dan motivasi belajar terhadap prestasi belajar IImu Fisiologi Olahraga.

\section{METODE}

Subyek dalam penelitian ini adalah seluruh mahasiswa semester III (tiga) Jurusan IImu Keolahragaan dan Jurusan IImu Kepelatihan Olahraga Fakultas Olahraga dan Kesehatan Universitas Pendidikan Ganesha Singaraja sebanyak 72 orang mahasiswa, terdiri atas dua (2) kelas, yaitu kelas Jurusan IImu Keolahragaan berjumlah 36 dan kelas Jurusan IImu Kepelatihan Olahraga berjumlah 36.

\section{Instrumen Penelitian}

Tes Prestasi Belajar:

Untuk memperoleh data yang berupa prestasi belajar IImu Fisiologi Olahraga, peneliti menggunakan instrumen penelitian berupa tes kemampuan (achievement test). Untuk memperoleh data mengenai prestasi belajar IImu Fisiologi Olahraga yang terdiri atas 30 butir soal yang dibuat oleh peneliti. Sebelum digunakan pada responden tes tersebut diujicobakan terlebih dahulu untuk mengetahui soal-soal yang memenuhi syarat penyusunan tes yang baik, diantaranya validitas dan reliabilitas.

Skor prestasi belajar mahasiswa diperoleh dengan menggunakan rumus sebagai berikut:

$$
\text { skor }=\frac{\text { jawaban benar }}{\text { jumlah soal }} \times 100
$$

\section{Angket Motivasi Belajar:}

Data yang berupa motivasi belajar di peroleh dengan menggunakan angket. Angket dalam penelitian ini terdiri dari 45 butir pertanyaan yang terdiri dari pertanyaan mendukung dan tidak mendukung. Tiap butir soal telah disertai 4 pilihan jawaban.
Keterangan selengkapnya mengenai ketentuan pemberian skor dalam angket adalah sebagai berikut:

Distribusi skor untuk pernyataan soal yang mendukung (+):

Selalu: 4

Sering: 3

Jarang: 2

Tidak Pernah: 1

Distribusi skor untuk pernyataan soal tidak mendukung (-)

Selalu: 1

Sering: 2

Jarang: 3

Tidak Pernah: 4

\section{Teknik Analisis Data}

Analisis data yang digunakan dalam penelitian ini adalah metode statistik dengan demikian

diharapkan dapat menyediakan dasardasar yang dapat dipertanggung jawabkan untuk menarik kesimpulan dan keputusan yang baik.Teknik

analisis yang digunakan adalah sebagai berikut:

\section{Uji normalitas}

Uji normalitas dilakukan untuk mengetahui apakah populasi terdistribusi normal. Uji normalitas menggunakan uji Lilliefors Kolmogorov Smirnov pada program SPSS 16.0

Apabila populasi terdistribusi normal maka analisis statistik yang digunakan adalah analisis statistik parametrik. Dan bila tidak terdistribusi normal menggunakan analisis statistik non parametrik.

\section{Uji Homogenitas}

Uji homogenitas di maksudkan untuk rnengetahui apakah populasi mempunyai varian yang sama. Dalam hal ini digunakan Uji Levene's pada program SPSS 16.0.

Apabila populasi homogen maka analisis statistik yang digunakan adalah analisis statistik parametrik. Dan bila tidak homogen menggunakan analisis statistik non parametrik. 


\section{Uji Hipotesis}

Uji hipotesis di lakukan untuk mengetahui apakah hipotesis dalam penelitian diterima atau ditolak. Dalam penelitian ini uji hipotesis menggunakan analisis variansi (anova) dua jalur dengan menggunakan. rumus :

$$
\mathrm{F}=\frac{M S_{P}}{M S e}
$$

Keterangan :

$\begin{array}{ll}\text { F : } & \text { Nilai Statistik uji F } \\ \text { MSp: } & \text { Rerata kuadrat perlakuan } \\ \text { MSc : } & \text { Rerata kuadrat skor }\end{array}$

Data yang diperoleh kemudian ditabulasikan dengan menggunakan desain faktorial 2x2 dan dianalisis menggunakan statistik uji $F$ (menggunakan anava dua jalur).

Tabel 3.3 Desain Faktorial $2 \times 2$

\begin{tabular}{|l|c|c|}
\hline \multirow{2}{*}{ MOTIVASI } & \multicolumn{2}{|c|}{ MODEL } \\
\cline { 2 - 3 } & $\begin{array}{c}\text { Kooperatif Tipe } \\
\text { Jigsaw } \\
\text { (A1) }\end{array}$ & $\begin{array}{c}\text { Konvensional } \\
\text { (A2) }\end{array}$ \\
\hline TINGGI (B1) & A1.B1 & A2.B1 \\
\hline RENDAH (B2) & A1.B2 & A2.B2 \\
\hline
\end{tabular}

Keterangan:

A1.B1 : Sel kelompok mahasiswa yang diberi model pembelajaran kooperatif tipe jigsaw dan memiliki motivasi belajar tinggi.

A2.B1 : Sel kelompok mahasiswa yang diberi model pembelajaran konvensional dan memiliki motivasi belajar tinggi.

A1.B2 : Sel kelompok mahasiswa yang diberi model pembelajaran kooperatif tipe jigsaw dan memiliki motivasi belajar rendah.

A2.B2 : Sel kelompok mahasiswa yang diberi model pembelajaran konvensional dan memiliki motivasi belajar rendah.

Setelah dilakukan, selanjutnya dikonsultasikan dengan tabel distribusi uji $\mathrm{F}$, Ho ditolak jika $\mathrm{F}<\mathrm{Fa}, F_{1}, F_{2}$, selanjutnya bila terdapat interaksi antara variable model pembelajaran motivasi belajar maka dilanjutkan dengan Uji Tuckey untuk mengetahui adanya perbedaan yang signifikan antar kelompok sel.

\section{HASIL DAN PEMBAHASAN}

1. Pengaruh model pembelajaran Kooperatif Tipe Jigsaw terhadap prestasi belajar Fisiologi Olahraga

Untuk menguji hipotesis yang menyatakan terdapat pengaruh model pembelajaran terhadap prestasi belajar Fisiologi Olahraga digunakan analisis variansi dua jalur. Berdasarkan hasil perhitungan analisis variansi dua jalur, diperoleh nilai $F=7,234$ dengan signifikansi
0,002 . Karena signifikansi $0,002 \quad(\leq 0,05)$ sehingga dapat dikatakan terdapat pengaruh yang signifikan dari penggunaan model pembelajaran terhadap prestasi belajar Fisiologi Olahraga. Berdasarkan hasil analisis data terlihat bahwa model pembelajaran Kooperatif tipe Jigsaw memperoleh rata-rata prestasi belajar yang lebih baik (mean $=60,81$ ) dibandingkan dengan pencapaian prestasi belajar dengan menggunakan model pembelajaran konvensional (mean $=60,21$ ). Menurut Qiao Mangduo dan Jin Xiaoling dalam Jigsaw Strategy as a Cooperative Learning Technique: Focusing on The Langage Learner (2010) menyatakan bahwa teknik jigsaw merupakan cara yang paling efektif dalam meningkatkan partisipasi siswa dalam belajar sehingga prestasi siswa dalam belajar bahasa meningkat. Hal ini juga 
disampaikan oleh Ahmad dan Akhmad Jezuli dalam Jigsaw Type of Cooperative Learning as a Means of Improving High School Students Mathematical Communication Ability (2009) yang menyatakan bahwa teknik jigsaw dapat meningkatkan prestasi belajar matematika jika dibandingkan dengan model konvensional.

2. Pengaruh motivasi belajar terhadap prestasi belajar Fisiologi Olahraga

Untuk menguji hipotesis yang menyatakan terdapat pengaruh motivasi belajar terhadap prestasi belajar Fisiologi Olahraga digunakan analisis variansi dua jalur. Berdasarkan hasil perhitungan analisis variansi dua jalur, diperoleh nilai $\mathrm{F}=$ 146,905 dengan signifikansi 0,000 . Karena signifikansi $0,000(\leq 0,05)$, sehingga dapat dikatakan terdapat pengaruh yang signifikan dari motivasi belajar terhadap prestasi belajar Fisiologi Olahraga. Berdasarkan hasil analisis data terlihat bahwa motivasi tinggi memperoleh rata-rata prestasi belajar yang lebih baik (mean = 71,05) dibandingkan dengan pencapaian prestasi belajar dengan motivasi rendah (mean = 50,00). Berdasarkan hasil penelitian Fyan dan Maehr tentang $A$ case study of cooperative learning and communication pedagogy mengatakan bahwa faktor motivasi sangat berperan dalam belajar. Walberg dkk menyimpulkan bahwa motivasi mempunyai kontribusi antara 11-20 persen terhadap prestasi belajar. Studi yang dilakukan Suciwati menyatakan bahwa motivasi berkontribusi sebesar 36\%, sedangkan McClleland menunjukkan bahwa motivasi berprestasi mempunyai kontribusi sampai $64 \%$ terhadap prestasi belajar.

3. Interaksi pengaruh antara model pembelajaran dan motivasi belajar terhadap prestasi belajar Fisiologi Olahraga

Untuk menguji hipotesis yang menyatakan terdapat pengaruh interaksi antara model pembelajaran dan motivasi belajar terhadap prestasi Fisiologi Olahraga digunakan analisis variansi dua jalur.
Berdasarkan hasil perhitungan analisis variansi dua jalur, diperoleh nilai $F=12,342$ dengan signifikansi 0,001 Karena signifikansi $0,001 \quad(\leq 0,05)$ sehingga dapat dikatakan terdapat pengaruh yang signifikan dari interaksi antara model pembelajaran dan motivasi belajar terhadap prestasi belajar Fisiologi Olahraga.

\section{SIMPULAN DAN SARAN}

1. Model pembelajaran Kooperatif tipe Jigsaw lebih efektif digunakan daripada model pembelajaran konvensional.

2. Terdapat pengaruh yang signifikan dari motivasi belajar terhadap prestasi belajar Fisiologi Olahraga.

3. Terdapat interaksi pengaruh antara model pembelajaran dan motivasi belajar terhadap prestasi belajar Fisiologi Olahraga. Adanya pengaruh dari interaksi antara model pembelajaran dan motivasi belajar mahasiswa terhadap prestasi belajar Fisiologi Olahraga menunjukkan bahwa dengan mengelompokkan mahasiswa yang mempunyai motivasi tinggi dan yang mempunyai motivasi rendah dapat mempengaruhi keefektifan model pembelajaran yaitu dengan model pembelajaran Kooperatif tipe Jigsaw dan konvensional dalam mempengaruhi prestasi belajar mahasiswa.

\section{SARAN:}

1. Bagi Dosen atau Tenaga Pengajar

a. Dosen Mata Kuliah Fisiologi Olahraga perlu menerapkan model pembelajaran Kooperatif Tipe Jigsaw dalam menyampaikan materi saat perkuliahan berlangsung yang sekiranya dapat dilaksanakan oleh mahasiswa di kelas. Dengan penerapan metode ini mahasiswa diharapkan akan lebih menyenangi proses belajar dan mampu mengeluarkan ide dan gagasan, memperluas wawasan dan meningkatkan pemahamannya.

Jurnal Pendidikan Indonesia | 143 
Pada akhirnya tujuan pembelajaran dapat dicapai secara optimal.

b. Dosen Fisiologi Olahraga sebaiknya memberikan motivasi kepada mahasiswanya dalam belajar karena motivasi belajar yang tinggi akan meningkatkan prestasi belajar.

2. Bagi Mahasiswa

a. Mahasiswa harus selalu belajar dan berani mengeluarkan ideidenya untuk mencapai prestasi yang diharapkan.

b. Mahasiswa harus bisa bekerjasama dengan orang lain

c. Mahasiswa harus mengetahui dan menumbuhkan motivasi berprestasinya untuk mencapai prestasi yang diharapkan.

3. Bagi Institusi

a. Pihak institusi harus menciptakan suasana lingkungan belajar nyaman dan memberikan kebebasan kepada mahasiswa untuk mengeluarkan dan mengembangkan ide-ide yang positif sehingga mereka dapat mencapai prestasi yang baik.Institusi harus menyediakan sarana dan prasarana yang memadai demi kelancaran proses pembelajaran dan tercapainya tujuan yang diharapkan.

\section{DAFTAR PUSTAKA}

Ahmad dan Jezuli A. 2009. "Jigsaw Type of Cooperative Learning as a Means of Improving High School Students Mathematical Communication Ability" in International Journal for Educational Studies Available at www.educare.ijes.com diakses tanggal 7 April 2011.

Lie A. 2010. Cooperative Learning. Jakarta: Penerbit Grasindo.

Qiao Mingdao and Jin Xiaoling. 2010. "Jigsaw Strategy as a Cooperative Learning Technique: Focusing on The Langage Learner" In Chinese Journal of Applied Linguistics Available at www.celea.org.en/teic/92/pdf diakses tanggal 7 April 2011

Sanjaya W. 2008. Strategi Pembelajaran, Jakarta: Kencana Prenada.

Suprijono A. 2010.Cooperative Learning. Jakarta: Penerbit Pustaka Pelajar.

Tsay, Mina and Brady, Miranda. 2010 "A case study of cooperative learning and communication pedagogy" in Journal of the scholarship of Teaching and Learning. Vol 10, No 2. Available at http:/ www.iupul.edu/josotl diakses 14 Maret 2011. 